\title{
The Effect of Transformational and Transactional Leadership Behaviours on Organizational Culture
}

\author{
Khan Muhammed RAJABI ${ }^{17}$ \\ Salih GÜNEY ${ }^{18}$ \\ Binnur GÜRÜL ${ }^{19}$
}

\begin{abstract}
This research was conducted in order to determine the effects and differences of demographic characteristics and transformational and transactional leadership behaviours of employees on organizational culture in an organization. Our study consists of four parts. In the first part, the concept of leadership, its definition, importance, and its difference from similar concepts will be examined. In the second part, the definition and basic dimensions of transformational and transactional leadership will be examined. In the third part, detailed information will be given on the definition of organizational culture, its importance, characteristics, and classification. In the last and fourth part of the study, research results will be given. Questionnaire technique was used in the study. Reliability test, normality test, and Kaiser-Meyer-Olkin (KMO) test were applied to the obtained data. As a result of the research, it was concluded that the demographic characteristics of the employees affect the organizational culture.
\end{abstract}

Keywords: Leadership, Transformational and Transactional Leadership, Organizational Culture

17 Khan Muhammed RAJABI, Istanbul Aydın University, hanmuhammed@gmail.com. ORCID: 0000-0003-4694-4421.

18 Prof. Salih GÜNEY, Istanbul Aydın University, salihguney@aydin.edu.tr, ORCID: 0000-0002-7565-5541.

19 Dr. Binnur Gürül, İstanbul Gelişim Üniversitesi, ORCID: 0000-0001-8708-702X.

DOI: 10.17932/IAU.FCPE.2015.010/fcpe_v06i2005 


\section{INTRODUCTION}

In the 20th century, organizational behaviour discipline, transformational, transactional leadership styles, and organizational culture have begun to become the focus of many scientists. They are the most researched concepts. With the emergence of globalization, increasing knowledge, constantly changing new products and technology in every field, the importance of concepts such as leadership, transformational and transactional leadership and organizational culture have started to increase.

When organizations started to place importance on human and human power, organizational behaviour discipline and organizational culture also gained importance and organizations continued to be renewed and developed in order to ensure their sustainability. Organizations have to adapt to constantly and rapidly changing internal and external environmental conditions and maintain their sustainability in the market and they are obliged to maintain the commitment of their employees to the organization and to further strengthen the organizational culture ties among them. Companies should employ leaders who will influence their employees in all aspects and increase their commitment to the organization so that they further adapt to the purpose and vision of the organization. Transformational and transactional leaders have important roles in creating a conscious and effective organizational culture in organizations. Transformational and

transactional leaders are what form the basis of organizational culture. There is a direct link between leadership and organizational culture.

\section{CONCEPT and DEFINITION of LEADERSHIP}

Leadership is a very broad and comprehensive concept. It is possible to find many definitions of leadership in the literature. While leadership was a religious and political concept that was frequently used only in primitive communities and military fields, today it has become an important component of organizational management and organizational culture due to technological developments. Throughout history, the concept of 
leadership has attracted the attention of researchers and a lot of noteworthy research has been conducted in this area.

There are many definitions of leadership put forward by different researchers. In the early 1920s, the role and importance of leadership in organizational management began to increase with the increasing impact of the Industrial Revolution and the introduction of high-tech products. The research on leadership conducted so far has resulted in various definitions of leadership. Despite this abundance of definitions, there is no generally accepted definition of leadership. People tend to live together due to their nature and socialization needs. Thomas Hobbes' «Leviathan,» Thomas More's «Utopia,» and J. J. Rousseau's «Social Contract» examine people's transition from living irregularly in the natural environment to living together and forming a society from different angles. For a human community, certain duties and responsibilities must be shared within the framework of certain rules. In order to allocate these duties and responsibilities among the individuals that make up the community, there is a need for a special individual from within that community (Çelik, 2000:1).

We can list some of the definitions about leadership as follows:

- Leadership is the ability and knowledge to influence and mobilize individuals by gathering them around predetermined goals and objectives (Güney, 2015: 26).

- Leadership is giving energy to the followers to do their duties better and the orientation process of this energy (Erdoğan, 2007: 486).

- Leadership is the art of mobilizing followers in line with specific goals and objectives (Fındıkçı, 2013: 55).

- It is the process of one person influencing and directing the behaviours of others in order to achieve predetermined individual, group, and organizational goals (Ataman, 2009: 543). 
- Leadership is the power to influence others. It is the ability to do something without putting pressure on others (Mansurova, 2017: 4).

Certain definitions of leadership have been addressed above. These definitions approach the concept from different aspects. Considering the dimensions of the leadership concept, it can be understood that there is no definite and clear definition that is generally accepted. Although there is no common definition, it is seen that researchers have similar views on leadership.

It can be said that the definitions related to the concept of leadership include the following elements (Güney, 2015: 26; Dümen, 2008: 38).

Goal: Common goals and interests that bring the members of the organization together.

Leader: It is the person who determines the purpose of the organization, ensures communication within the group; it is a creative person who regulates and organizes.

Leadership: It is the ability and knowledge to gather individuals around specific goals and to influence and mobilize them to achieve these goals.

Followers: These are the subordinates who follow the leader's influence.

Environment: It is the basic element that emerges from variables such as the competence of the individuals in every aspect, the clarification of the goals and objectives of the organization, and the motivation level of the followers.

If the common aspects of all leadership definitions are summarized briefly, it is possible to talk about a group of people and the common goals that this group is trying to achieve, and an effective, talented, and knowledgeable leader in achieving the group's goals. 


\section{FOUNDATIONS of LEADERSHIP}

When the publications of the researchers on leadership are studied, it will be seen that the concept of leadership is formed by the combination of some main elements (Güney, 2015: 37). The cornerstones of leadership are:

Providing Motivation: The person in charge of the organization as the leader should ensure that their followers feel the importance of their own work so that they appreciate and adopt the goals of the organization. The leader should motivate subordinates to reach the goals of the organization (Özalp ve Kırel, 1992: 165-167).

Appreciation and Congratulation: The leader should show the members that they like their work by sincerely praising them and making them feel how important they are to the organization. As a leader, they must show their commitment to their followers and clearly express gratitude to them. These behaviours of leaders positively affect the performance of the employees.

No Gender Discrimination Between Followers: The leader should take care not to make any gender discrimination between men and women while moving towards the goals and objectives of the group. It is in the interest of the society and the organization that all followers work together. A person in the position of a leader moves away from the leadership position as soon as they begin to discriminate among the followers and lead the organization to failure (Güney, 2011: 37).

\section{LEADERSHIP RULES}

Saying «I am the leader of this society,» does not make a person a real leader. The person in the leader's position should have certain characteristics and qualities. The leader must comply with the norms and rules specified in leadership definitions. It is imperative that the person who claims leadership grows and develops themselves. Otherwise, it will cause great harm to both the leader and the followers in the society, and it will drag the group into crisis. Some norms that can be considered as a prerequisite for leadership are addressed below (Güney, 2015: 55). 
One should know and improve oneself: An impressive leader must first know themselves. They must know their own weaknesses and strengths, strengthen their weaknesses, and improve themselves in every aspect.

\section{The person should have sufficient knowledge and experience:} Knowledge and experience are the most fundamental elements for leadership. It is not possible for a leader without knowledge and experience to lead the society in real terms. Leaders who cannot answer the society's questions and find solutions to its problems lose their dignity and become an object of derision. A leader should be like a complete resource in terms of knowledge and experience. In other words, the society should feel that it can find an answer and a solution in the leader for every problem it faces. The leader has earn the society's trust (İnce and Oktay, 2006: 19).

The leader should have a sense of responsibility: The leader has a responsibility for the followers' goals and objectives. A leader should fulfil this responsibility in the most critical times, clearly, and without wasting any time (Baykal, 1998: 137).

The leader should set objectives and goals: The person in the leader's position should set original objectives, goals, and dreams for the society and the organization. Only when these objectives and goals are achieved true leadership is demonstrated.

The leader should be able to make appropriate and timely decisions: It is the ability to make decisions even in the most difficult conditions that makes a true leader. A rational, logical, and worthy leader is able to make and implement healthy decisions even in the most difficult times (Tuncer, 2011: 68-70).

\section{THE DIFFERENCE BETWEEN LEADER AND MANAGER}

In order to better understand the difference between leader and manager, it will be useful to refer to the definitions of both concepts. Management is a concept that describes the processes of planning, organizing, and controlling the activities within the group in line with the goals of the organization. It is the art of managing people. 
Leadership: It is the skill of guiding, shedding light, and persuading the employees in order to realize common goals and objectives (Erdoğan, 2007: 488).

Manager: It is someone who employs smarter people than themselves.

Leader: It is the person who motivates the followers by influencing them in every aspect.

The differences between Leader and Manager are shown in Table 1 below.

Table 1: Differences Between Manager and Leader

\begin{tabular}{cc}
\hline MANAGER & LEADER \\
Administrator & Innovative \\
Keeps the order & Makes a difference \\
Sustains & Improves \\
Structure-centered & Human-centered \\
Tends to control & Trusts \\
Wide perspective & Narrow perspective \\
Asks "How" and "When" & Asks "What" and "Why" \\
Considers the lower limits & Considers the environment \\
Accepts the current situation & Challenges the current situation \\
Acts in accordance with the norms & Can go beyond the norms \\
Does things right & Does the right things \\
Copyist & Original \\
Authoritarian & Risk-taker \\
Encourages & Directs \\
Asks questions & Gives answers \\
Fives more importance to ideas & Rigid \\
\hline
\end{tabular}

Source: Güney, 2012: 43, Akyar, 2011: 276-277.

Both concepts are based on achieving predetermined goals and objectives of employees. Leader and manager are both the source of power for employees and followers.

There is a fundamental difference between the leader and the manager. As stated in the table above, the leader predicts the events and changes in advance, while the manager aims for keeping the order in the same way. 
The manager does not want changes and does not become happy when there are changes in the organization. If organizations desire efficiency, sustainability, and success, they should employ or train employees and staff with both leadership and managerial characteristics. Otherwise, continuous innovation, change, and competition in our age will make it difficult for organizations to adapt to time (Güney, 2012: 42, Keçicioğlu, 1998: 10).

\section{FORMS OF POWER USED IN THE LEADERSHIP PROCESS}

The concept of leadership is closely related to the concept of power. Taking a leader's role depends on that person's attitude, personality traits and behaviour towards the group members and their acceptance of them as a leader. It is closely related to the power of influence they have. In order to influence individuals, the person in the leading position must use their power from time to time. A person in the position of a leader should know very well what types of power they have, which type of power to use, and when, where, and how to use it. When they are aware of the forms of power they have and when they can use appropriately, they will reach the leadership quality and this will make them more effective and successful than other people (Derya, 2010: 9-27). It is possible to come across many definitions regarding the concept of power. Some of these definitions are addressed below (Güney, 2015: 10, Sinanoğlu, 1998: 82, Mansurova, 2017: 8).

Power is the ability of a person (or group) to influence another person (or group).

Power is an ability required to influence people's behaviour.

Power is the ability of an individual or group to influence and control the decisions, attitudes, and behaviours of others.

Power is the ability of a person to influence another person to follow their own orders or a rule of their choice. The forms of power used in the leadership process are as follows. 
Leader and Legal Power: Legal power is defined by researchers as legitimate, legal power. It is also known as the strength of the position an individual has. Legal power is the type of power that results from the status of the leader and manager in the organization. The power of an individual to influence and direct their followers due to their official status is the legal power. According to some researchers, it is necessary to monitor and control leaders and managers who rely too much on legal power and who use their legal power frequently against their followers. Otherwise, the effectiveness of legal power may decrease. The person in the position of leader takes legal power from their position. For the followers at lower levels, there is an obligation to follow the orders given by the leader due to the status of the leader. To the leader's use of legal force against the subordinates, subordinates can respond with their own legal power as well. Just as managers have job descriptions in laws and regulations, employees also have job descriptions in the same resources (Minister and Büyükbeşe, 2010: 76).

Leader and Power Based on Liking (Charismatic Power): Charismatic power is a power based on personality traits. It is a special type of power that arises from a person's aura. Its origin is completely inherent. If the leader is a respectful person, their instructions are more easily accepted and followed by subordinates. The personality traits of a leader are discussed more than the formal and legal power. With this power, the charismatic leader manages the subordinates, inspires them and gives them hope. Due to charismatic power, subordinates more easily accept some attitudes and behaviours they do not like in the leader. The essence of this power lies in the completely voluntary fulfillment of the leader's orders by the subordinates through their own free will. Leaders evoke a sense of admiration in their subordinates due to this special power they possess. Subordinates adopt them as a role model because they admire the leader. Charismatic power is much broader and more extensive than any other force. However, there are very few people who have this power. Great leader Mustafa Kemal Atatürk had natural leadership qualities. His stance, behaviour, love and respect for the public, intelligence and courage are a perfect example of charisma (Bayrak, 2001: 27). 
Leader and Expertise Power: The power that a leader has and that followers need, based on knowledge and skills, is called expert power. The subordinates, who see the expertise of their leader, accept and trust the decisions and judgments made by them more easily. Expert power in leadership is not constant; it may increase or decrease. If the knowledge and skills of a leader are accepted by subordinates, their expertise power increases. If the leader's decisions are found to be wrong and incomplete, that leader's expertise power decreases. On the other hand, the fewer people in the organization who have a command of the knowledge, experience, and technical skills of the leader, the more expertise power the leader has. Therefore, leaders should always follow the agenda and be closely involved with the internal and external affairs and the organizational changes. Leaders must always improve the amount of knowledge they have. Otherwise, they may lose their expertise over time. In order not to lose the expertise power they have; leaders should be in the position of a problem solver and a source of information for their subordinates. The staff class in organizations and military institutions is the best example of this power (Güney, 2015: 66).

Power of Rewarding: Rewarding is a right. Leaders can influence their subordinates by playing a role in wage increases and promotions in organizations. Since leaders have the right to use formal types of awards in institutions and organizations, they can mobilize their subordinates in line with the determined goals and objectives by using their power resulting from award-giving. Rewarding practices consist of awards such as salary increase, premium payment, promotion, appreciation, increasing authority and responsibilities, increasing status, praising, etc. (Güney, 2015: 65).

Power of Punishment: It is the power that arises when people do not act in accordance with the organization's goals and objectives. It is the opposite of the power of rewarding. It expresses the leader's power to punish the subordinates. It is a form of power based on fear. For this reason, anything that invokes fear in the followers is a source of power (Güney, 2015: 65). 


\section{TRANSFORMATIONAL AND TRANSACTIONAL LEADERSHIP}

Transformational leader: The definition of transformation in the dictionary is «transforming into a different form, changing shape, transformation, revolution, alternation», but it is also expressed as «bringing something from one level to another» (TDK, 2019). The transformational leadership concept used by James V. Downton for the first time was addressed by the author in his work titled «Rebel Leadership» and the concept (Transformational Leadership) has entered the literature with the work named «Leadership» published by James McGregor Burns in 1978. The concept of transformational leadership may take place in Turkish sources as a reformer, transformations, changer, transformative leader (Koçel, 2018: 608).

The Concept and Definition of Transactional Leadership: It is stated that transactional leadership, which was conceptualized by Burns and examined by many researchers, especially Bass, is more traditional than transformational leadership. It is based on the transactions between the leader and their followers (Luthans, 2011: 431). Transactional leadership, in its simplest form, refers to the exchange between the leader and the followers. The basis of the abovementioned exchange is the leader and the employees gathering together and determining the tasks that need to be completed, and agreeing on the rewards and punishments to be given to them based on whether these tasks are done in the desired way by the subordinates (Bass, 1998: 4; Bass, 1990b: 20). Due to the nature of social exchange, the leader, on the one hand, controls the behaviour of the followers by using power and authority, and on the other hand, responds to their requests and needs. In order to ensure the willingness and obedience of the followers to work, the transactional leader, using organizational resources, makes a special effort to involve their subordinates in the process and to change their values. A kind of stimulus-response model is utilized to control and correct adverse behaviour. (Grundstein-Amado, 1999: 250-251). The transactional leader is known as a form of leadership that was first disclosed by Burns. According to most researchers, the main basis of this theory is adherence to bureaucratic authority and laws. The transactional leader follows the goals and objectives that lead the 
organization to success by distributing responsibilities to their followers. If the organization achieves success and the desired values, its followers are rewarded, and if it fails, they are punished. The transactional leadership system is evaluated as a leadership style based on reward and punishment.

\section{Comparison of Transformational and Transactional Leadership:} McGregor Burns discussed the distinction between transactional leader and transformational leader, based on the managerial teachings of Herbert A. Simon and Weber's source of economic and non-economic authority in relation to political leadership. It was named transactional leader (managerial, traditional leadership) and transformational leadership theory was developed due to the failure of this leadership approach in the face of newly developing economic and social conditions. The first studies on this issue were conducted to specify the qualities that make transformational leadership different from transactional leadership (Allix, 2000: 10).

Leadership is defined by Burns in his work titled "Leadership" as putting people into action by taking advantage of political, economic or similar powers and values to achieve their independent or mutual goals. The most important point in the definition is the objectives, which are independent from each other but also related. Two people can exchange goods and services mutually in order to achieve an independent goal. In this type of relationship, there is a bargain, not a joint effort, for followers to achieve their common interests. The situation in question arises from the transactional leadership approach. Leaders' changing and shaping the goals and values of their followers using only the leadership process, on the other hand, is all about transformational leadership. Both of the leadership approaches stated above can be used for the benefit of humanity. If the behaviour between the leader and the followers makes it possible for the goals of both sides to be achieved, then the transactional leadership will satisfy the followers. The formative values of the transactional leader are determination, correctness, and responsibility. The areas of interest for the transformational leader are equality, freedom, and justice that are to be built upon the former. The transformational leader aims to increase the morale and motivation level of the followers through the latter values stated above (Burns, 1978: 425-426). 
Tichy and Devanna (1986: 343), on the other hand, explain the differences between transformational leadership and transactional leadership, as in Table 2.

Table 2: Differences Between Transactional and Transformational Leadership

\begin{tabular}{ccc}
\hline & Transactional & Transformational \\
\hline Time orientation & Short, today & Long, future \\
Coordination & Rules and guidelines & Unity of objectives and \\
Contact & Vertical, top to bottom & Versatile \\
Focus & Financial goals & Customer (internal and \\
Reward system & Organizational, external & Personal, internal \\
Source of power & Status & Followers \\
Decision making & Centralized, Top down & Participated, Bottom up \\
Employee & Seen as property & Seen as a developable \\
Obedience & Commandment & Rational explanation \\
Attitude towards & Avoiding, Resisting, and Protecting the & Not Avoiding, Adapting \\
Juidance Mechanism & Earnings & Vision and values \\
Inspection & Excessive harmony & Self-control \\
Perspective & Internal & External \\
Duty planning & Segmented, individual & Enriched, grouped \\
\hline
\end{tabular}

Resource: Tichy and Devanna, 1986: 343.

\section{CULTURE, THE CONCEPT AND DEFINITION OF ORGANIZATIONAL CULTURE}

The concept of culture, which has more than 100 definitions in the literature, was explained in the 1750 s as «the way of life of the human being.» According to Taylor, who was the most referenced name in those years, culture is «a complex whole that includes knowledge, faith, art and morality, customs and traditions, habits and all skills of a person as a member of a society.» (Gunner, 2012: 1281).

Culture, which is a deeply rooted concept, is a concept of interest to different fields of humanities and social sciences and is mainly a research subject of social anthropology. It is predicted that the concept of culture is derived from the Latin word «colere» or «culture,» which are originally used to mean «nurture, look» (Smith, 2009).

It is known that the Romans used the term «cultura» to distinguish between the plants planted by people in a field and the plants that grow 
by themselves in the natural environment. Again, the term «agri-cultura», meaning «cultivating the land,» was coined by the Romans to correspond to the term «agriculture.» In this sense, the term culture still lives today. The word «ekin» (kultur), which is suggested as the equivalent of the word «culture» in Turkish, has been derived to meet the meanings of «to plant, to cultivate» in the verb "colere.» The fact that the concept of culture covers different fields and has different aspects, as well as being an abstract concept, brought along various definitions made from various aspects. For this reason, culture has been the subject of research in many different disciplines such as psychology, history, political science, anthropology, and sociology and it has been defined by different disciplines with different emphasis (Seymen, 2008: 2).

Importance of Organizational Culture: There have been many studies recently drawing attention to the importance of organizational culture. Because the importance of culture for any group of people, society, country, and business organization has been noticed recently. Groups evolve into organizations as people work together to achieve goals. As goals become more specific and longer term and jobs become more specialized, organizations become both formal and institutional.

Features of Organizational Culture: Many features of organizational culture can be addressed, but in general, we can list the features of organizational culture as follows (Güney, 2015: 188-189, Vural et al., 2007: 45).

- It is symbolic,

- It is a reflection of top management,

- It can be understood and felt without being expressed,

- It has a stable structure,

- It is distinctive and characteristic

- It is accepted. 


\section{EXAMINATION OF THE EFFECT OF TRANSFORMATIONAL AND TRANSACTIONAL LEADERSHIP BEHAVIORS ON ORGANIZATIONAL CULTURE}

\section{Purpose of the study}

People spend a large part of their lives working. During these times, people want to both meet their own wishes and expectations and be cheerful and peaceful. Of course, there are some responsibilities that fall on the employee for all these to happen. Due to the constantly changing and renewed technological products and intense competitive environments in our age, organizations need a knowledgeable, experienced, and effective leader and a reliable organizational culture in order to reach their predetermined goals and objectives and their future vision. The aim of the study is to reveal that these two phenomena are not separate from each other, but in fact, they are concepts that complement each other.

\section{The population and sample of the research}

The population of the research consists of employees working at the public and private sectors in Istanbul. The sample of the study consists of 234 participants.

\section{Methodology of the research}

In our research, our data collection method was determined as the questionnaire. In the first part, the personal information of the participants was included. While analyzing the dimensions of multifactorial leadership (transformational and transactional leadership) in the second part, the Kaiser-Meyer-Olkin (KMO) test was applied to the dimension of organizational culture in the last part.

\section{Data analysis}

SPSS (Statistical Package for Social Scientist) 18 was used for our survey analyses and the analysis methods to be used were determined according to the results of the normality analysis. As a result of normality analysis, according to Shapiro-Wilk and Kolmogorov - Smirnov tests: "The scale 
does not have a normal distribution at 95\% confidence level" hypothesis was accepted. Nonparametric tests were applied depending on the result. In addition to these, reliability analysis and frequency analysis were also applied.

\section{Research hypotheses}

Hypothesis 1: Organizational culture shows a statistically significant difference according to the gender of the employees.

Hypothesis 2: Organizational culture shows a statistically significant difference according to the age groups of employees.

Hypothesis 3: Organizational culture shows a statistically significant difference according to the education level of employees.

Hypothesis 4: Organizational culture shows a statistically significant difference according to the positions of the employees in the institution.

Hypothesis 5: Organizational culture shows a statistically significant difference according to the total period of time employees worked in the institution.

\section{RESULTS}

Frequency and percentage distributions of the demographic variables are shown in Table 3 below. 
Table 3: Frequency distribution of personal characteristics of individuals

\begin{tabular}{lll}
\hline Variable & $\mathbf{n}$ & $\mathbf{\%}$ \\
\hline Age & & \\
\hline $20-30$ & 38 & 16.2 \\
$31-40$ & 85 & 36.3 \\
$41+$ & 111 & 47.5 \\
\hline Total & $\mathbf{2 3 4}$ & $\mathbf{1 0 0}$ \\
\hline Gender & & \\
\hline Female & 97 & 41.5 \\
Male & 137 & 58.5 \\
\hline Total & $\mathbf{2 3 4}$ & $\mathbf{1 0 0}$ \\
\hline Education Level & & \\
\hline High School & 7 & 3.00 \\
Associate Degree - Undergraduate & 89 & 38.0 \\
Graduate Degree or higher & 138 & 59.0 \\
\hline Total & $\mathbf{2 3 4}$ & $\mathbf{1 0 0}$ \\
\hline Status & \multicolumn{3}{l}{} \\
\hline Manager and Director & 28 & 12.00 \\
Doctor or Nurse & 144 & 61.5 \\
Administrative Staff & 62 & 26.5 \\
\hline Total & $\mathbf{2 3 4}$ & $\mathbf{1 0 0}$ \\
\hline Service & 82 & \\
\hline Less than 5 years & 77 & 35.0 \\
6-10 years & 75 & 32.9 \\
11-15 years & $\mathbf{2 3 4}$ & $\mathbf{1 0 0}$ \\
\hline Total & \multicolumn{2}{l}{}
\end{tabular}

When the table regarding the demographic characteristics of the sample group is examined, it is seen that $38(16.2 \%)$ of the participants in the sample group are in the 20-30 age group, $85(36.3 \%)$ are in the $31-40$ age group, and $111(47.5 \%)$ are 41 years old and above. $97(41.5 \%)$ of the participants are female and $137(58.5 \%)$ are male. $7(3 \%)$ of the participants have a high school degree, $89(38 \%)$ have an associate or undergraduate degree, and $138(59 \%)$ have a graduate or higher degree. 28 of the participants $(12 \%)$ are managers or directors, $144(61.5 \%)$ are doctors or nurses, and $62(26.5 \%)$ are administrative staff. It was observed that 82 of the participants (35\%) have a seniority of less than 5 years, 77 (32.9\%) have $6-10$ years, and $75(32.1 \%)$ have $11-15$ years. The correlation analysis between transactional leadership behaviours and organizational culture is shown in Table 4 below. 


\section{CORRELATION ANALYSIS}

Table 4: Correlation Analysis Between Transactional

Leadership Behaviours and Organizational Culture

\begin{tabular}{|c|c|c|c|c|c|c|c|c|c|c|c|}
\hline Dimensions & Avg. & $\begin{array}{l}\text { Std. } \\
\text { Dev. }\end{array}$ & 1 & 2 & 3 & 4 & 5 & 6 & 7 & 8 & 9 \\
\hline $\begin{array}{l}\text { Management with Passive People and } \\
\text { Passive/Avoidant Leadership }\end{array}$ & 2.11 & 0.91 & $\longrightarrow$ & & & & & & & & \\
\hline Conditional Reward & 3.64 & 0.74 & $\overline{0} .301 * *$ & - & & & & & & & \\
\hline Management with Active People & 3.02 & 0.81 & $0.189^{* *}$ & $0.276^{* *}$ & - & & & & & & \\
\hline Transactional Leadership & 2.72 & 0.53 & $0.787^{* *}$ & $0.160^{*}$ & $0.643^{* *}$ & - & & & & & \\
\hline Power Distance & 2.95 & 0.70 & $0.283^{* *}$ & 0.008 & $0.223^{* *}$ & $0.317^{* *}$ & - & & & & \\
\hline Avoiding Uncertainty & 3.94 & 0.61 & $-\overline{-}^{-} 276^{* *}$ & $\begin{array}{l}0.303 \\
* *\end{array}$ & -0.043 & $-0.154^{*}$ & 0.012 & - & & & \\
\hline Masculinity/Femininity & 2.71 & 1.00 & $0.362^{* *}$ & -0.07 & 0.103 & $0.336^{* *}$ & $0.378^{* *}$ & $\overline{0} .176^{* *}$ & - & & \\
\hline Individualism/Collectivism & 3.87 & 0.63 & $\overline{0} .259^{* *}$ & $0.231^{* *}$ & -0.097 & $-0.153^{*}$ & $-0.104^{*}$ & $0.287^{* *}$ & 0.074 & - & \\
\hline Organizational Culture & 3.34 & 0.46 & $0.193^{* *}$ & 0.100 & $0.141^{*}$ & $0.270^{* *}$ & $0.612^{* *}$ & $0.276^{* *}$ & $0.765^{* *}$ & $0.359^{* *}$ & - \\
\hline
\end{tabular}

The table above shows the relationship between transactional leadership behaviours and organizational culture, and when the table is examined, the following relationships between the variables were found: weak positive correlation between perceptions of Management with Passive People and Passive/Avoidant Leadership and Power Distance $(\mathrm{p}<0.01 ; \mathrm{r}$ $=0.283$ ), weak negative correlation between perceptions of Management with Passive People and Passive/Avoidant Leadership and Uncertainty Avoidance ( $\mathrm{p} 0.01 ; \mathrm{r}=-0.276$ ), moderate positive correlation between perceptions of Management with Passive People and Passive/Avoidant Leadership and Masculinity/Femininity $(\mathrm{p} 0.01 ; \mathrm{r}=0.362)$, weak negative correlation between perceptions of Management with Passive People and Passive/Avoidant Leadership and Individualism/Collectivism ( $\mathrm{p} 0.01 ; \mathrm{r}=$ -0.259), weak positive correlation between perceptions of Management with Passive People and Passive/Avoidant Leadership and Organizational Culture ( $\mathrm{p} 0.01 ; \mathrm{r}=0.193$ ), moderate positive correlation between perceptions of Conditional Reward and Avoidance of Uncertainty ( $\mathrm{p} 0.01$; $r=0.303$ ), weak positive correlation between perceptions of Conditional Reward and Individualism/Collectivism ( $\mathrm{p} 0.01 ; \mathrm{r}=0.231$ ), weak positive correlation between perceptions of Management with Active People and Power Distance $(\mathrm{p} 0.01 ; \mathrm{r}=0.223)$, weak positive correlation between 
perceptions of Management with Active People and Organizational Culture ( $\mathrm{p} 0.05 ; \mathrm{r}=0.141$ ), moderate positive correlation between perceptions of Transactional Leadership and Power Distance ( $\mathrm{p} 0.01 ; \mathrm{r}=0.317)$, weak negative correlation between perceptions of Transactional Leadership and Uncertainty Avoidance ( $\mathrm{p} 0.05 ; \mathrm{r}=-0.154)$, moderate positive correlation between perceptions of Transactional Leadership and Masculinity/ Femininity ( $\mathrm{p} 0.01 ; \mathrm{r}=0.336$ ), weak negative correlation between perceptions of Transactional Leadership and Individualism/Collectivism ( $\mathrm{p} 0.05 ; \mathrm{r}=-0.153$ ), weak positive correlation between perceptions of Transactional Leadership and Organizational Culture ( $\mathrm{p} 0.01 ; \mathrm{r}=0.270)$ The correlation analysis between transformational leadership behaviours and organizational culture is shown in Table 5 below.

Table 5: Correlation Analysis Between Transformational Leadership Behaviours and Organizational Culture

\begin{tabular}{|c|c|c|c|c|c|c|c|c|c|c|c|c|}
\hline Dimensions & Avg. & $\begin{array}{l}\text { Std. } \\
\text { Dev. }\end{array}$ & 1 & 2 & 3 & 4 & 5 & 6 & 7 & 8 & 9 & 10 \\
\hline $\begin{array}{l}\text { Idealized Effect } \\
\text { (Behavioural/Qualitative) }\end{array}$ & 3.78 & 0.63 & - & & & & & & & & & \\
\hline Intellectual Stimulation & 3.65 & 0.74 & $0.443^{* *}$ & - & & & & & & & & \\
\hline Inspirational Motivation & 3.71 & 0.66 & $0.532 * *$ & $0.543 * *$ & $\longrightarrow$ & & & & & & & \\
\hline Individual Support & 3.68 & 0.84 & $0.361^{* *}$ & $0.386^{* *}$ & $0.356^{* *}$ & - & & & & & & \\
\hline Transformational Leadership & 3.72 & 0.55 & $0.819 * *$ & $0.752 * *$ & $0.798 * *$ & $0.600^{* *}$ & - & & & & & \\
\hline Power Distance & 2.95 & 0.70 & -0.09 & -0.052 & -0.022 & 0.052 & -0.071 & - & & & & \\
\hline Avoiding Uncertainty & 3.94 & 0.61 & $0.229 * *$ & $0.178^{* *}$ & $0.175^{* *}$ & $0.275^{* *}$ & $0.283^{* *}$ & 0.012 & - & & & \\
\hline Masculinity/Femininity & 2.71 & 1.00 & $\overline{-} .275^{* *}$ & $\overline{-}-207^{* *}$ & -0.048 & $-0.165^{*}$ & $\overline{-}-248^{* *}$ & $0.378^{* *}$ & $\overline{-}-176^{* *}$ & & & \\
\hline Individualism/Collectivism & 3.87 & 0.63 & $0.204 * *$ & 0.116 & $0.283^{* *}$ & $0.143^{*}$ & $0.258^{* *}$ & -0.104 & $0.287^{* *}$ & 0.074 & - & \\
\hline Organizational Culture & 3.34 & 0.46 & -0.083 & -0.014 & 0.101 & 0.045 & -0.012 & $0.612 * *$ & $0.276^{* *}$ & $0.765^{* *}$ & $0.359 * *$ & - \\
\hline
\end{tabular}

The table above shows the relationship between transformational leadership behaviours and organizational culture, and when the table is examined, the following relationships between the variables were found: weak positive correlation between the perceptions of Idealized Impact (Behavioural/Qualitative) and Uncertainty Avoidance ( $\mathrm{p}<0.01 ; \mathrm{r}=$ 0.229 ), weak negative correlation between the perceptions of Idealized 
Effect (Behavioural/Qualitative) and Masculinity/Femininity ( $\mathrm{p} 0.01 ; \mathrm{r}=$ -0.275), weak positive correlation between the perceptions of Idealized Effect (Behavioural/Qualitative) and Individualism/Collectivism ( $\mathrm{p} 0.01 ; \mathrm{r}=0.204$ ), weak positive correlation between the perceptions of Intellectual Stimulation and Uncertainty Avoidance (p0.01; $r=0.178$ ), weak negative correlation between the perceptions of Intellectual Stimulation and Masculinity/Femininity (p0.01; $r=-0.207$ ), weak positive correlation between the perceptions of Inspirational Motivation and Uncertainty Avoidance ( $\mathrm{p} 0.01 ; \mathrm{r}=0.175)$, weak positive correlation between the perceptions of Inspirational Motivation and Individualism/ Collectivism ( $\mathrm{p} 0.01 ; \mathrm{r}=0.283$ ), weak positive correlation between the perceptions of Individual Support and Avoidance of Uncertainty ( $\mathrm{p} 0.01 ; \mathrm{r}=0.275$ ), weak negative correlation between the perceptions of Individual Support and Masculinity/Femininity (p0.05; $r=-0.165$ ), weak positive correlation between the perceptions of Individual Support and Individualism/Collectivism ( $\mathrm{p} 0.05 ; \mathrm{r}=0.143$ ), weak positive correlation between the perceptions of Transformational Leadership and Uncertainty Avoidance $(\mathrm{p} 0.01 ; \mathrm{r}=0.283)$, weak negative relationship between the perceptions of Transformational Leadership and Masculinity/Femininity (p0.01; $r=-0.248$ ), weak positive correlation between the perceptions of Transformational Leadership and Individualism/Collectivism (p0.01; $\mathrm{r}=$ $0.258)$.

\section{REGRESSION ANALYSIS}

Variables associated with organizational culture as a result of correlation analysis were included in the regression analysis and multiple regression analysis was performed. Since the perception of Transformational Leadership and its sub-dimensions were not related to organizational culture, the effect of transformational leadership behaviour on organizational culture has not been examined. The effect of transactional leadership behaviours and its sub-dimensions on organizational culture is shown in Table 6 below. 
Table 6: The Effect of Transactional Leadership Behaviours and Its SubDimensions on Organizational Culture

\begin{tabular}{lccc}
\hline Independent Variable & \multicolumn{1}{c}{$\mathrm{t}$} & $\mathrm{p}$ \\
Constant & 2.797 & 14.24 & 0.000 \\
Management with Passive People and Passive/Avoidant Leadership & -0.086 & -1.04 & 0.300 \\
Management with Active People & -0.135 & -1.89 & 0.061 \\
Transactional Leadership & 0.415 & 2.27 & 0.024 \\
F & & 4.155 & \\
Model (p) & & 0.007 & \\
$\mathbf{R}^{2}$ & & 0.051 & \\
\hline
\end{tabular}

The table above shows the effect of transactional leadership behaviour on organizational culture. Regression coefficients were tested with t statistics, and Transactional Leadership $(p<0.05)$ was found to be statistically significant in the regression equation that explains organizational culture. Management with Passive People and Passive/Avoidant Leadership ( $\mathrm{p}=$ $0.300)$ and Management with Active People $(p=0.061)$ are not significant in the explanation. One unit increase in the Transactional Leadership behaviour score causes a 0.415 -fold increase in the constant anxiety score. Transactional Leadership has a statistically significant effect on organizational culture. Explanatory coefficient, which is the percentage of independent variables explaining the model as a result of the multiple linear regression analysis ) is 0.051 . The regression equation that was found to be statistically significant is as follows.

Organizational Culture $=2.797-0.086$ (Management with Passive People and Passive/Avoidant Leadership) -0.135 (Management with Active People) +0.415 (Transactional Leadership).

\section{CONCLUSION}

The second scale, which aims to measure the participants' attitudes towards transformational leadership behaviours that consists of 20 items, was developed on the basis of five dimensions: idealized effect (behavioural), idealized effect (qualitative), inspiring motivation, intellectual stimulation, and individual support perception. In order to reveal the attitude perception factor design related to transformational leadership behaviours, principal 
component analysis was chosen as the factorization method, and maximum variability from vertical rotation methods was chosen as the rotation method. Cronbach's Alpha test values of the four sub-dimensions of the transformational leadership behaviours scale show that the reliability level of the scale is sufficient.

The 19-item organizational culture scale, which aims to measure participants' attitudes towards organizational culture, has been developed on the basis of four dimensions: power distance, escape from uncertainty, masculinity/ femininity, and individualism/collectivism perception. In order to reveal the attitude perception factor design related to organizational culture, principal component analysis was chosen as the factorization method, and maximum variability from vertical rotation methods was chosen as the rotation method. Cronbach's Alpha test values for the four sub-dimensions of the organizational culture scale show that the reliability level of the scale is sufficient. Factor analysis results of all three scales were shown in tables in detail in the findings section.

Considering the analysis of the age variable, it was seen in the comparison table of the transactional leadership behaviours scale that the participants' perceptions of management with passive people and passive/avoidant leadership, conditional reward, and management with active people subdimensions showed a statistically significant difference in different age groups. It was observed that the median of management with passive people and passive/avoidant leadership perception of the participants in the 31-40 age group was statistically significantly higher than of those above the age of 41 . This shows that the 31-40 age group prefers passive leadership more than those above the age of 41 . It was observed that the median of conditional reward perception of the participants aged 41 and above was statistically significantly higher than those in the 20-30 and 31-40 age groups. Participants aged 41 and above are more receptive to conditional reward. The median of management with active people perception of the participants aged 41 and above is again statistically significantly higher than those in the 31-40 age group. This age group prefers a more active 
management than the 31-40 age group. When the comparison table regarding the scale of organizational culture was examined, it was seen that the participants' perceptions of power distance, masculinity/femininity, and organizational culture showed a statistically significant difference according to gender. It was observed that the median of men's perception of power distance, masculinity/femininity, and organizational culture was statistically significantly higher than that of women.

When it comes to the analyses related to the seniority variable, when the comparison table of the transactional leadership behaviours scale was examined, it was seen that the participants' perceptions of transactional leadership behaviour and its sub-dimensions did not show a statistically significant difference according to seniority. In the same way, it was observed that the scores related to leadership behaviour perceptions and to its sub-dimensions and the scores related to organizational culture perceptions and to its sub-dimensions do not show a statistically significant difference according to seniority.

Regarding the analysis of the job title variable, when the comparison table of the transactional leadership behaviours scale was examined, it was seen that the scores of participants' perceptions of transactional leadership and its sub-dimensions did not show a statistically significant difference according to the job title. Finally, when the comparison table of the transactional leadership behaviours scale was examined regarding the analysis of the education level variable, it was seen that the participants' perceptions of transactional leadership behaviours and its sub-dimensions did not show a statistically significant difference according to the education level.

When the comparison table regarding the transformational leadership behaviours scale was examined, it was seen that the idealized effect (behavioural/qualitative) perceptions of the participants showed a statistically significant difference according to their education level. It has been observed that the median of idealized effect (behavioural/qualitative) perception of participants with a graduate or higher degree is statistically significantly higher than those with an associate or undergraduate degree. 
When the comparison table regarding the scale of organizational culture was examined, it was seen that the scores related to participants' perceptions of organizational culture and its sub-dimensions did not show a statistically significant difference according to their education level.

When the transactional leadership behaviours and organizational culture correlation analysis table is examined, there is a positive weak relationship between the perceptions of management with passive people and passive/ avoidant leadership and power distance, a weak negative relationship between perceptions of management with passive people and passive/ avoidant leadership and uncertainty avoidance, a moderate positive relationship between the perceptions of management with passive people and passive/avoidant leadership and masculinity/femininity, a weak negative relationship between the perceptions of management with passive people and passive/avoidant leadership and individualism/collectivism, a weak positive relationship between the perceptions of management with passive people and passive/avoidant leadership and organizational culture, a moderate positive relationship between the perceptions of conditional reward and uncertainty avoidance, a weak positive relationship between the perceptions of conditional reward and individualism/collectivism, a weak positive relationship between the perceptions of management with active people and power distance, a weak positive relationship between the perceptions of management with active people and organizational culture, a positive relationship between the perceptions of transactional leadership and power distance, a weak negative relationship between the perceptions of transactional leadership and uncertainty avoidance, a moderate positive relationship between the perceptions of transactional leadership and masculinity/femininity, a negative relationship between the perceptions of transactional leadership and individualism/collectivism, a weak positive relationship between the perceptions of transactional leadership and organizational culture.

When the transformational leadership behaviours and organizational culture correlation analysis table is examined, there is a weak positive relationship 
between the perceptions of idealized effect (behavioural/qualitative) and avoiding uncertainty, a weak negative relationship between the perceptions of idealized effect (behavioural/qualitative) and masculinity/femininity, a weak positive relationship between the perceptions of idealized effect (behavioural/qualitative) and individualism/collectivism, a weak positive relationship between the perceptions of intellectual stimulation and uncertainty avoidance, a weak negative relationship between the perceptions of intellectual stimulation and masculinity/femininity, a weak positive relationship between the perceptions of inspirational motivation and uncertainty avoidance, a weak positive relationship between the perceptions of inspirational motivation and individualism/collectivism, a weak positive relationship between the perceptions of individual support and uncertainty avoidance, a weak negative relationship between the perceptions of individual support and masculinity/femininity, a weak positive relationship between the perceptions of individual support and individualism/collectivism, a weak positive relationship between the perceptions of transformational leadership and uncertainty avoidance, a weak positive relationship between the perceptions of transformational leadership and uncertainty avoidance, a weak negative relationship between the perceptions of transformational leadership and masculinity/femininity, a weak positive relationship between the perceptions of transformational leadership and individualism/collectivism.

Multiple regression analysis was performed by including variables related to organizational culture that were found as a result of correlation analysis. Since the perception of transformational leadership and its sub-dimensions were not related to organizational culture, the effect of transformational leadership behaviour on organizational culture has not been examined. 


\section{REFERENCES}

[1] Akyar A. (2011). Lider Yönetici Adayının El Kitabı, Etkili Yönetim ve Yöneticilik 1, İlya Yayınevi, İzmir.

[2] Allix M. Nicholas. (2000). "Transformational Leadership, Democratic or Despotic?", Educational Management \& Administration, 28(1), pp.720.

[3] Ataman G. (2009). İşletme Yönetimi, Türkmen Kitabevi Yayınları, İstanbul.

[4] Bakan İ. Büyükbeşe T. ve Bedestenci Ç. (2004-2010). Örgüt Sırlarının Çözümünde - Örgüt Kültürü, Aktüel Yayınları, Bursa.

[5] Bass B. M. \& Riggio, R.E. (2006). Transformational Leadership 2 end. Mahwah, NJ: Lawrence Erlbaum.

[6] Bass B. M.(1990-1998). "From Transactional to Transformational Leadership: Learning to Share The Vision", Organizational Dynamics. 18(3), pp. 19-31.

[7] Baykal A. N. (1998). Yöneticiler İçin Yeni Bir Bakış: Mustafa Kemal Atatürk'ün Liderlik Sırları, Nordstern İmtaş Yayınları, İstanbul.

[8] Bayrak. S. (2001). "Yönetimde Bir İhmal Konusu Olarak Güç ve Güç Yönetimi-II”, SDÜ İktisadi ve İdari Bilimler Fakültesi Dergisi, Cilt: 6, Sayı 1.

[9] Burns J.M. (1978). Leadership, New York: Harper \& Row.

[10] Çelik K, Vehbi, (2000), Eğitimsel Liderlik, Pegem Yayıncılık, Ankara.

[11] Derya S. (2010). "Liderlik Tarzları ve Liderlerin Astlarını Etkileme Taktikleri Arasındaki İlişki: Antalya İli 5 Yıldızlı Otel Yöneticileri Üzerinde Bir Araştırma", (Yayınlanmamış Yüksek Lisans Tezi), Süleyman Demirel Üniversitesi, İşletme Fakültesi, Isparta. 
[12] Dümen G. (2008). “Dönüşümcü Liderlik Davranışlarının Personelin İş Tatminine Etkisi ve Bir Askeri Birlikte Uygulama Çalışması", (Yayınlanmamış Yüksek Lisans Tezi), Gazi Üniversitesi, İşletme Fakültesi, Ankara.

[13] Erdoğan İ. (2007). İşletmelerde Davranış, MİAD Yayınları, İstanbul.

[14] Fındıkçı İ. (2013). Hizmetkâr Liderlik, Alfa Yayınları, İstanbul.

[15] Grundstein, Amado R. (1999). "Bilateral Transformational Leadership: An Approach for Fostering Ethical Conduct In Public Service Organizations", Administration and Society. 31(2), pp.247-260.

[16] Güney. S. (2011). Örgütsel Davranış, Nobel Yayınları, Ankara.

[17] Güney. S. (2012-2015). Liderlik, Nobel Yayınları, Ankara.

[18] İnce M. ve Oktay E. (2006). "Bilginin Bir Stratejik Güç Olarak Önemi ve Örgütlerde Bilgi Yönetimi”, Selçuk Üniversitesi Karaman İ. İ. B. F. Dergisi, Sayı 10, Y11 9.

[19] Keçecioğlu. T. (1998). Liderlik ve Liderler, KalDer Yayınları, İstanbul.

[20] Koçel. T. (2011, 2018). İşletme Yöneticiliği, Beta Basım, İstanbul.

[21] Luthans F. (2011). Organizational Behavior: An Evidence-Based Approach, Twelfth Edition, McGraw-Hill Book Company.

[22] Mansurova. N. (2017). 'İşletmelerde Dönüşümcü Liderlik Davranışlarının Örgüt Kültürüne Etkisi ve Bir Uygulama', ,(Yayınlanmamış Yüksek Lisans Tezi), İstanbul Aydın Üniversitesi.

[23] Özkalp, E. ve Kırel, Ç. (1992-2004). Örgütsel Davranış. 6. Bask1, Anadolu Üniversitesi Yayınları, Eskişehir. 
[24] Seymen O.A. (2008). Örgütsel Bağl1lığ1 Etkileyen Örgüt Kültürü Tipleri Üzerine Bir Araştırma, Ankara: Detay Yayıncılık.

[25] Sinanoğlu. A. F. (2006). “Atatürk’ün Kişiliğinde Bilgelik Vasfinın Tezahürü ve Toplum Hayatına Yansıması”, AÜİF Dergisi, Cilt: 47, Sayı 1.

[26] Smith, P. (2001-2009). Cultural Theory: An introduction. Blackwell: Oxford University Press. York: Harper\&Brothers.

[27] Tichy N. M., \& Devanna M. A. (1986). The Transformational Leader, New York: John Wiley.

[28] Tuncer. P. (2011). “Örgütsel Değişim ve Liderlik”, Sayıştay Dergisi, Sayı: 80.

[29] Türk Dil Kurumu, 2019.

[30] Vural, Z. Beril Akıncı, \& Coşkun, Gül. (2007). Örgüt Kültürü: İletişim, Liderlik, Motivasyon, Bağlılık, Performans Açısından Değerlendirme. Nobel Yayın Dağıtım. 